\title{
THE INSTITUTION OF INDIVIDUAL INTERPRETATIONS OF TAX LAW AS PROVIDED UNDER THE AMENDED PROVISIONS OF THE TAX CODE
}

2005 marked the introduction of the institution of binding tax law interpretations into the Polish legal system. A period of less than THREE years of operation of these rules has demonstrated that these solutions ARE FAR FROM PERFECT. A number of deficiencies and weaknesses has made their practical application difficult for taxable persons, payers, collectors, legal successors of the taxable person, as well as for third parties responsible for tax arrears, and of course, the tax authorities. The case-law of administrative courts only confirms this state of affairs.

This institution has been amended in response to indicated problems, and entered into force in its modified form on $1^{\text {st }}$ July $2007 .{ }^{1}$ In this paper, we will present some of the solutions provided under the amendment with regard to individual tax law interpretations. An attempt of a partial assessment will also be made, based on the views of the academic world.

First of all, it must be stressed that the new system of providing individual interpretations was based on the following premises:

- centralization of providing written interpretations (apart from interpretations regarding local taxes),

- the interpretation as an autonomous (separate from an order) legal form of an administrative act,

- detailed definition of the application for an interpretation of tax law provisions,

- modification of the structure of the rationae personae and rationae materiae for the interpretation of tax law, 
- direct (although not a quite) challenge of interpretations before an administrative court. ${ }^{2}$

In the author's opinion the amendment of the T.C. could be treated as a revolution in the sphere of tax law interpretation as it does not deprive tax payers from their hitherto privileges, and provides for more privileges at the same time. Moreover, it is directed at the elimination of the weaknesses arising from the previous provisions, which hindered reaching uniform decisions on the interpretation of tax law provisions by various tax authorities.

The T.C. amendment introduced a new chapter entitled "Tax law interpretations". The collection, practically, of all rules regarding binding tax information under a separate chapter resulted in quite a clear reorganization of this institution. The underlying reason for such a far-reaching reconstruction of rules governing the obtaining official information on the application of tax law by the applicants was the urgency of providing uniformity.

Based on the experience, the legislator made the assumption that the existing system of providing binding tax information failed to satisfy its requirements. The information provided to taxpayers was not uniform, and accordingly, they could not have been considered to be a credible and reliable source of knowledge on tax legislation. Frequent divergences in the legal assessment of identical facts presented by tax authorities in various regions of the country hardly served the purpose of building the taxpayer's trust of tax administration authorities. This, in turn, weakened the prestige of these authorities in the eyes of the taxpayers, which in some cases may have been a cause of their diminished effectiveness.

This situation made the reconstruction of the whole system of providing tax information to taxpayers a necessity. The Minister of Finance became the most important player of the institution of binding tax law interpretations being responsible for providing information to taxpayers ex officio, as well as upon their application instead of the authorities mentioned above. However, this does not pertain to interpretations regarding taxes, the collection of which is vested in local governments.

In accordance with the amended legislation - very much like before - two types of interpretations are to be provided: of a general nature, provided "ex officio", and individual interpretations, provided in response to a specific written query of the applicant. The consequences of taxpayer compliance with these two types of binding właściwego do spraw finansów publicznych (Individual interpretations of tax law provided by the competent minister for public finance) Part 1, Monitor Podatkowy (Tax Monitor), 5/2007, p. 22. 
tax law interpretations will cease to be differentiated. ${ }^{3}$ We will only discuss the most important changes with regard to individual tax law interpretation.

The first primary change is the centralization of providing tax law interpretations. This is a direct result of the contents of the new provisions, according to which the competent minister for public finance provides a written interpretation of tax law legislation at the written application of the party concerned, with regard to this party's individual case. ${ }^{4}$ This scheme differs from the previous regime, according to which interpretations regarding the scope and manner of application of tax law had been provided for the taxpayer by the competent tax authorities. The adoption of such a scheme of the legal regulation is directed at providing uniformity of the contents of replies provided for taxpayers. However, as it appears from the implementing regulation to the amended legislation, ${ }^{5}$ in practice the directors of four tax chambers (Bydgoszcz, Katowice, Poznań and Warsaw) perform the Minister's duties. As regards local taxes, individual interpretations are provided by the prefect, mayor or the president of city. The Tax Code also provides that interpretations may be provided by the heads of counties and voivodeship marshals; however, as both the county and voiviodeship do not have any taxes of their own, in practice, these authorities do not possess such competences.

With the amendment of the T.C, taxpayers may benefit from the application template for a tax law interpretation - ORD-IN- developed by the Ministry of Finance, which resembles a traditional PIT (Personal Income Tax) return. The Minister of Finance defined the template by the Regulation of $20^{\text {th }}$ June 2007 on the template of a tax law interpretation application and the manner the application fee is paid. ${ }^{6}$ First of all, this template has enabled the applicant: to provide his/her identity details in a proper manner; to provide information whether the application refers to an existing factual situation or to future events; exhaustive and proper presentation of the facts or future event; and the appropriate presentation of the applicant's position regarding the case, accompanied by a legal assessment of the described factual situation or future event.

The amendment has also covered the expenses of providing interpretations. Presently, the fee has been increased to 75 PLN (payable within 7 days following the submission of the application) for each presented factual situation (or future event), even if they are included in one application. ${ }^{7}$

3 M. Sobońska, Nowelizacja ustawy - Ordynacja podatkowa: omówienie najistotniejszych zmian (The Tax Code: discussion on the most important changes), Przegląd Podatkowy (Tax Review), No. 2 (190), February 2007, pp. 26-27.

$4 \quad$ Article $14 \mathrm{~b}(1)$ of the T.C.

5 The Ordinance of the Minister of Finance of 20th June 2007 regarding the authorization for providing tax law interpretations (Journal of Laws of 2007, No, 112, item 770).

6 (Journal of Laws of 2007, No, 112, item 771).

7 The Ordinance of the Minister of Finance of 20th June 2007, op. cit. 
An important element of the discussed amendment as regards the application is also the obligation of submitting a statement under of criminal liability for providing a false statement: that the elements of the factual situation covered by the application for an interpretation on the date of submitting the application, are not the subject of pending tax proceedings, tax audit, audit proceedings of a tax audit authority; and that to this extent the matter has not been resolved as to its merits by decision or order of a tax authority or tax audit authority. In the event of submitting a false statement, the provided individual interpretation shall have no legal effect.

According to the Ministry of Finance representatives, the RD-IN application template and the statement mark an improvement in the use of the institution of the interpretation of tax legislation by taxpayers, and simplify the processing of applications for an interpretation. On the other hand, the academic world is of the opinion that this is one more application form that will bear an adverse influence on the operation of the institution of the interpretation of tax law. ${ }^{8}$

The rationae personae and rationae materiae of the application has also changed. First of all, the group of entities that may apply for an individual tax law interpretation has been broadened. Apart from the entities that may submit an application, that is, taxable persons, payers, collectors, legal successors of the taxable person, as well as third parties responsible for tax arrears, such an application may also be submitted by an entities which, in the future, may have the status of taxable persons, payers, collectors, legal successors of the taxable person, as well as third parties responsible for tax arrears.

On the other hand, the subject of interpretation has been broadened by the already mentioned option of providing an interpretation regarding a future event. Apart from the legal assessment of an already existing factual situation, this solution is a great step in the taxpayer's favour. It is possible to apply for an interpretation of a future investment, and accordingly, make a realistic assessment of the tax safety when it is implemented. ${ }^{9}$

The form of an individual interpretation has also undergone a change, as it is now a letter of the Minister of Finance, addressed to the applicant with regard to his/her specific case (until $1^{\text {st }}$ July 2007, this was an order or a decision). The said solution

8 Parliamentary question of 16th August 2007, No. 9238.

9 M. Sobońska, op. cit. p. 28. 
was criticized consensually by both the academic world ${ }^{10}$ and case-law ${ }^{11}$, as under the pervious regime, written interpretations of tax law were delivered in the form of an order (possibly a decision of second instance authority). It has been stressed that the T.C. provisions created numerous interpretative problems, including, but not limited to, the determination in what form should the resolution of the second instance authority be delivered - a decision or order; and if in the form of a decision, then is this a decision of the first or second instance. The scheme adopted, which followed the 2007 amendment is to be deemed as correct, as it sets the question of tax law interpretation in order and explains its legal nature. One must share the views of that part of the academic world, and with some administrative court caselaw, that acts of interpreting tax law cannot be considered as means of applying law, as the form of a decision or order is solely reserved for resolutions with a view of applying the law. ${ }^{12}$

A substantial change is also the lack of the binding force of the interpretation for the authority which has provided such an interpretation. However, this provision is mitigated by Article 19 of the T.C., which has set forth a general rule that compliance with an individual interpretation cannot have an adverse effect on the applicant in the event of a change of the interpretation or it is not given consideration in the resolution of the tax matter.

The deadline for providing an interpretation has also changed, as the Minister of Finance provides it without undue delay, within the 3 months following the receipt of the application ${ }^{13}$. The scheme, according to which the 3-month time-period does not include periods that were necessary for performing certain acts, periods of a stay of proceedings or delays caused at the party's fault, or for reasons beyond the authority's control is a novelty. It is criticized by the academic world, as application proceedings may be substantially extended within the bounds of law if such a situation is justified by the Minister by numerous cases.

10 See, inter alia, A. Bartosiewicz, R. Kubacki, Wiążące interpretacje podatkowe - fatalne zmiany (Binding tax interpretations - fatal modifications) , „Glosa” (“The Gloss”) 2004, No. 11; G. Dźwigała, Wiażące interpretacje prawa podatkowego - problemy postępowania (Binding tax interpretations - procedural problems), „Przegląd Podatkowy" ("Tax Review”) 2004, No. 11; W. Stachurski, Wiążące interpretacje przepisów prawa podatkowego w orzecznictwie sądów administracyjnych (Binding tax legislation interpretations in the case-law of administrative courts) -, [in:] Urzędowe interpretacje prawa podatkowego w Polsce i innych krajach Europy Środkowej i Wschodniej (Official tax law interpretations in Poland and in other states of Central and Eastern Europe) „Białostockie Studia Prawnicze” ("Białystok Legal Studies”), 2006, pp. 72-84.

11 See, inter alia, the order dated 28th October 2005 of the Voivodeship Administrative Court in Warsaw, file No. III SA/Wa 2065/05 (unpublished), judgment dated 31st August 2005 of the Voivodeship Administrative Court in Białystok file No. I SA/Bk 178/05 (unpublished), order dated 21st June 2005, Voivodeship Administrative Court in file No. I SA/td 497/05 (unpublished).

12 G. Dudar, Skarga sądowoadministracyjna na pisemną interpretacje przepisów prawa podatkowego wydawana $w$ indywidualnej sprawie (The administrative court complaint against a written tax law interpretation provided in an individual case), Zeszyty Naukowe Sądownictwa Administracyjnego (Academic Journals of the Administrative Judiciary), No. 3 (18)/2008, Warsaw 2008, p. 93. 
The T.C. amendments which have been in force since $1^{\text {st }}$ July 2007 also provide that a taxpayer, dissatisfied with the received tax law interpretation, may appeal to an administrative court. However, the authority which provided the interpretation must first be summoned upon in writing to compensate for the breach of law before the appeal to the Voivodeship Administrative Court of the appropriate competent jurisdiction is lodged ${ }^{14}$. The summons should be submitted within a 14-day period after the tax interpretation has been served. The summons is the equivalent of a remedy and is applicable in the situations, where there is no appeal authority that may make a decision as to the legality of a challenged resolution, within the bounds of its competence. In practice, this involves the necessity of another review of the matter by the Minister of Finance, and to be more precise, by the authorized four tax chambers. The necessity of summoning the Minister of Finance to review the matter once more is also provided under the provisions of the Administrative Courts Procedure Act. ${ }^{15}$ As it has already been mentioned, the party dissatisfied with the contents of the written tax interpretation provided by the Minister of Finance - prior to lodging a complaint with the administrative court - must summon the Minister of Finance to provide a cure for the breach of law. The complaint may be lodged with the court only after the reply to the summons in question has been received, or when the period of 60 days of ineffective waiting for a response has expired.

It must be stressed that the omission of the summons stage to cure the breach of law results in the rejection of the complaint by the court, as it had been lodged prematurely. It is worth mentioning that in practice, it is also possible to submit a motion for the instigation of mediation proceedings before an administrative court, which, at least in principle, provides the taxpayer with the objective possibility of a genuine discussion with the Minister of Finance.

The amendments of the T.C. presented above, with regard to tax law interpretations, are the subject of substantial criticism from the academic world. These allegations, in principle, refer to all modifications introduced by the discussed amendment, due to their nature, designated as "unfriendly to the taxpayer". 


\section{Streszczenie}

Instytucja wiążących interpretacji prawa podatkowego do polskiego systemu prawnego została wprowadzona w 2005 r. Niespełna trzyletni okres jej funkcjonowania pokazał, że przyjęte rozwiązania są dalekie od doskonałości. Wiele słabych punktów w jej konstrukcji w znacznym stopniu utrudniło praktyczne zastosowanie przez podatników, płatników, inkasentów, następców prawnych oraz osób trzecich i oczywiście przez same organy podatkowe. Orzecznictwo sądów administracyjnych tylko potwierdza ten stan rzeczy.

Przepisy regulujące wiążące interpretacje zostały znowelizowane w odpowiedzi na pojawiające się problemy i weszły w życie z dniem 1 lipca 2007 r. Niniejszy referat przedstawia niektóre rozwiązania przewidziane w nowelizacji indywidualnych interpretacji prawa podatkowego. Autor częściową ocenę nowych rozwiązań dokonuje również w oparciu o poglądy doktryny w tym zakresie. 